\title{
THE CONCEPT OF “GENRE” IN THE ASPECT OF PHILOSOPHICAL HERMENEUTICS
}

\section{Goroshkina O. M., Mordovtseva N. V.}

\section{INTRODUCTION}

The problem of the genre, has already been within view of many researchers for a long time. The genre is considered in philosophical, literary, linguistic, pedagogical literature, which authenticate complexity and multidimensional nature of the concept. This has led to discussion about studying of various aspects of genre theory: from the genres typology to the features of genre communication. Despite the diversity of researchers views on the phenomenon of "genre", they are united by an understanding of the genre in terms of communicational activity.

In the second half of the twentieth century, scholars attention began to attract genres from different communicative spheres, which led to the appearance of genre oriented research within a number of related, but at the same time different according to methodological orientation of science. Genres have become the subject of other philological fields, including rhetoric, functional stylistics, text linguistics, cognitive linguistics, and applied linguistics. It is possible to say that the term "genre" in its modern meaning covers a variety of standardized forms of communication that belong, without exception, to all spheres of public life. The intensification of genre studies made possible the separation of an independent discipline, for the name of which in 1938 the Canadian researcher P. van Tigem proposed the term genology, emphasizing the importance of studying genres and their leading role in philological theories and empirical research.

Hermeneutics as an art of interpreting the deep meanings of texts has also acquired the status of a separate humanitarian field. Various aspects of the problem of interpreting a text from a hermeneutic standpoint have been studied by F. de Saussure, P. Hartmann, R. Jacobson, and others. The results of the study of philosophical aspects of the text are presented to different extet in the works of V. Rudnev, M. Foucault, E. Benvenist, R. Bart, M. Bakhtin, Y. Kristeva, etc.

Recently, hermeneutics is defined as the theory and practice of interpretation of speech works represented by signs, symbols and texts ${ }^{1}$ and

\footnotetext{
${ }^{1}$ Kemerov, V. E. Kerimov, T. H. (2003). Sotsialnaya filosofiya [Social philosophy] : slovar. Moskva : Akademicheskiy proekt. 560 p.
} 
also as the science of understanding the meaning of speech works ${ }^{2}$; the art of explication, aimed at revealing the true meaning of the text ${ }^{3}$; an important resource for the formation of linguistic personality, which has the ability to express their thoughts orally or in writing form ${ }^{4}$.

At the same time, there is a lack of research of the pedagogical communication genres, represented by signs, symbols and texts. The problem of studying genres in a hermeneutic context also needs special study.

\section{Genre and text as an object of theoretical analysis}

For a long time, philologists have used next definition of the genre "a variety of texts of a certain style that diverge primarily by the purpose of speech, communication sphere and other features". However, according to the analysis of the scientific literature, ideas about the genre and its role have changed radically - from its recognition as a leading art category to complete denial. Nowadays, the category of genre is one of the important elements of language description, because the entire structural organization of human speech is largely determined by the genre differentiation of texts. The intensification of genre studies made it possible to separate an independent discipline, name of which in 1938 proposed the Canadian researcher P. van Tigem. He called it genology, emphasizing the importance of studying genres and their leading role in philological theories and empirical theories ${ }^{5}$. An analysis of the special literature in retrospective made it possible to establish, that genealogy, which stood out as a branch of linguistics in the XX century, has a long traditions, as its origins date back to ancient Greece and Rome.

As a result of the analysis and synthesis of literary works, it was found ${ }^{6}$ that for the concept of "genre" as a key category of literary development is possible to synthesize the general artistic patterns and individual

\footnotetext{
${ }^{2}$ Nikolyukin, A. N. (2001). Literaturnaya entsiklopediya terminov i ponyatiy [Literary encyclopedia of terms and concepts]. Moskva : Intelvak. 1600 p.

${ }^{3}$ Reber, A. (2000). Bolshoy tolkovyiy psihologicheskiy slovar [Big explanatory psychological dictionary]. Moskva : Veche, AST. Tom 2. 560 p.

${ }^{4}$ Galitskih, E. O. (2007). Germenevticheskiy podhod k formirovaniyu yazyikovoy lichnosti na urokah literaturyi [A hermeneutic approach to the formation of a linguistic personality in literature lessons]. Russkaya literatura $\mathrm{v}$ formirovanii sovremennoy yazyikovoy lichnosti. Sankt-Peterburg. P. 38-45.

5 Johns, M. Ann (1995). Genre and Pedagogical Purposes. Genre and Pedagogical Purposes San Diego State University. Journal of second language writing, 4 (2), P. 181-190. URL: https://www.sciencedirect.com/sdfe/pdf/download/eid/1-s2.0-10603743 95900063/first-page-pdf.

${ }^{6}$ Halych, O., Nazarets, V., Vasyliev, Ye. (2000). Teoriia literatury [Theory of literature]. Kyiv : Lybid. P. 251.
} 
achievements of writers. In literary criticism, the genre is defined as "a historically formed type of work of art, which synthesize the characteristics of the content and form of a particular type of study. It also has a relatively stable compositional structure, which is constantly evolving and enriching".

For many linguistic research, study of M. Bakhtin who defined the genre as "stable, fixed by routine and circumstances forms of life communication", became an impuls ${ }^{7}$. According to the scientist, the genre is a collectiveindividual regulator of a complex process of human communication. Bakhtin explore traditional genres, pointing on their strict regulations, separate existence, clear boundaries and the use of only "its" material. Genre groups have certain traditions and "frameworks" for authors. The researcher spoke about the canon of the genre - "a certain system of stable and solid genre features" .

In M. Bakhtin's theory, genres are interpreted as integral statements that have a functional, socially conditioned nature. Certain social functions and certain conditions specific to each sphere of speech, creates genres which diversity is unlimited, as well as the richness and variability of types and forms of social life. The researcher distinguishes two classes among genres: "simple genres" regular communication and "complex genres" (novels, dramas, essays). According to T. Yakhontova, M. Bakhtin's concept "is more than just a formal description of texts. He contrasts them with a static concept based on stylistic purism and exclusivity"9.

For a long time, Bakhtin's scientific position determined the vector of linguistic research. Partly under the influence of the scientist's ideas in the second half of the last century there was a rethinking in such sciences as rhetoric, stylistics, text linguistics, cognitive linguistics and applied linguistics. Although genre concepts in these areas have in common an indisputable recognition of the social nature of genres, there is still some variability due to the emphasis on the study or extralingual essence of genres, or their verbal features. According to M. Bakhtin and V. Voloshinov, language realization build up through specific expressions that change depending on the type of activity. "Speech transformed into genres which direct language cooperation and are defined by social structures. They organize our speech in the same way as grammatical forms. We learn to design our speech in the form of genres, and then, hearing the speech

${ }^{7}$ Bahtin, M. I. (1979). Problemyi rechevyih zhanrov [Problems of speech genres]. Estetika slovesnogo tvorchestva. Moskva : Iskusstvo. P.237-280.

${ }^{8}$ Bahtin, M. (1975). Voprosyi literaturyi i estetiki. Issledovaniya raznyih let [Questions of literature and aesthetics. Research of different years]. Moskva : Hudozhestvennaya literatura. $500 \mathrm{p}$.

9 Yakhontova, T. V. (2009). Linhvistychna henolohiia naukovoi komunikatsii [Linguistic genealogy of scientific communication] : monohrafiia. Lviv : Vydavnychyi tsentr LNU imeni Ivana Franka. 420 p. 
from others, we guess the genre from the first words and we also predict a certain length and a certain compositional structure. We can predict the ending, this means, that from the very beginning we perceive speech as a whole, which is become detailed later in the process of speech"10.

The theoretical analysis of the genre received a second chance in the 90s of the last century. The beginning of the second millennium was marked by active theoretical and practical researches in this field. The change of the language system of views from system-centric to anthropocentric and intensive development of new directions of linguistics and related sciences (pragmatics, linguoculturology, communicational ethnography, sociolinguistics) contributed to the fact that in the early nineties of the XX century in linguistics, the concept of "genre" increasingly has been used in communicative and social contexts. Note that the term "genre" in its modern meaning covers a variety of standardized forms of communication that belong to all spheres of public life, without exception.

Analysis of the scientific literature shows that today there are many definitions of the concept of "genre", which become an indicator of the multi-vector orientation of research. An attempt to interpret the essence of genres, their fundamentally new meanig, took place under the influence of the above-mentioned literary approaches and also thanks to the M. Bakhtin theory of speech genres, which significantly influenced the modern vision of the genesis and features of various genres.

The genre category is inextricably linked with the concept of "text". The multifunctionality of the text determines various approaches to its definition, for example, approaches that reflect the nature of the functioning of the concept in different scientific fields: ontological, epistemological; actually linguistic; psychological; pragmatic ${ }^{11}$.

The definitions are based on such basic factors as the form of speech (written and oral or only written), structural and semantic unity of elements, the number of authors (only monologue or monologue and dialogue), title (presence or absence), number of sentences in the text (texts from one sentence or from several), etc.

In linguistics, the most complete definition of the text was proposed by I. Halperin. The researcher interprets the text as a work of speech-making process, distinguished from others by its completeness, which is designed as a written document and also literary processed according to the type of this

10 Yakhontova, T. V. (2009). Linhvistychna henolohiia naukovoi komunikatsii [Linguistic genealogy of scientific communication] : monohrafiia. Lviv: Vydavnychyi tsentr LNU imeni Ivana Franka. 420 p. P. 34.

${ }^{11}$ Turaeva, Z. Ya. (1986). Lingvistika teksta: (Tekst: struktura i semantika) [Linguistics of the text: (Text: structure and semantics)]. Moskva : Prosveschenie. 126 p. 
document. It consists of name (title) and a number of special units united by different types of lexical, grammatical, logical, stylistic connection, and has a certain purposefulness and pragmatic guidance ${ }^{12}$.

According to O. Selivanova, "text (from the Latin, textus - fabric, plexus, combination) - comprehensive semiotic form of linguo-psychomental activity of the speaker, conceptually and structurally integrated, which serves as a pragmatic mediator of communication" ${ }^{\prime 3}$. In this definition, the text is presented as the activity of the speaker, a component of culture.

T. Yeshchenko defines the text as "an oral, written or printed structurally and conceptually organized verbal unity, which is a mediator and at the same time the final realization (result) of communication, a phenomenon of language usage; form of embodiment of living discourse after its completion"14. The researcher considers the text from the position of pragmalinguistics, sociology, rhetoric, communication theory, genre theory. Summarizing the various definitions of the text, the scientist notes that the text as a linguistic phenomenon can be qualified in terms of the following aspects: 1) the mediator and at the same time the final result of communication; 2) the structure in which the living discourse is embodied after its completion; 3) the phenomenon of language usage; 4) verbal unity, structurally and conceptually organized, expressed in written, oral or printed form; 5) a work that correlates with one of the genres of fiction or non-fiction ${ }^{15}$. This confirms the multifunctionality of the text as a scientific unity.

In the Encyclopedia "Ukrainian language" the text is interpreted as a written or oral speech array, which is a linear sequence of utterances, united in the short term semantic and formal-grammatical ${ }^{16}$.

The existence of different approaches to the interpretation of the concept of "text" is due to a number of reasons. Modern Ukrainian researcher O. Selivanova includes the following: absolutization of the structural organization of the text and grammatical means of communication; formalstructural, genre-stylistic diversity of texts and the specifics of the way of

${ }^{12}$ Galperin, I. R. (1981). Tekst kak ob'ekt lingvisticheskogo issledovaniya [Text as an object of linguistic research]. Moskva : Nauka. 138 p.

${ }^{13}$ Selivanova, E. A. (2002). Osnovyi lingvisticheskoy teorii teksta i kommunikatsii [Foundations of linguistic theory of text and communication] : monografiya. Kiev : TsUL, Fitosotsiotsentr. P. 600-601.

${ }^{14}$ Yeshchenko, T. A. (2009). Linhvistychnyi analiz tekstu [Linguistic analysis of the text] : navchalnyi posibnyk. Kyiv : Akademiia. 263 p.

${ }^{15}$ Ibid. P. 40-41.

${ }^{16}$ Ukrainska mova. Entsyklopediia (2007). [Ukrainian language. Encyclopedia] / Redkolehiia : Rusanivskyi V. M., Taranenko O.O., Ziabliuk M.P. ta inshi. 3-e vydannia, zi zminamy i dopovnenniamy. Kyiv : Ukrainska entsyklopediia imeni M. P. Bazhana. 856 p. 
their representation; multifaceted approaches to the linguistic study of the text (ontological, epistemological, linguistic, psychological, pragmatic, communicative, modal, structural, nominative, cognitive, socio-historical); narrowing of the text function to the level of the component of the communicative process, mediator, means, process and purpose of communication, absolutization as part of the definition of a certain category or several categories of text ${ }^{17}$.

The concepts of "genre" and "text" are correlated with each other, because the genre is a clear and relatively stable organization of the text. The choice of genre depends on a number of objective and subjective factors. A notable feature of the text is the presence of the necessary genre components. At the same time, the text always reflects the logic of the author's thinking, represents his vocabulary, the peculiarities of the use of language. We share the scientific position of $\mathrm{O}$. Benyuk, who notes that "in modern philosophical discourse, the concept of text reaches far beyond its original meaning"18. Since the concepts of "genre" and "text" are interdependent, there is a need to consider the phenomenon of the text in a philosophical context.

\section{Terminological essence of the "text" concept in hermeneutic and pedagogical paradigms}

The phenomenon of the text and related issues have become the subject of a thorough analysis in the philosophical aspect. Traditionally, this analysis has focused mainly on the problems of understanding, interpretation, meaning formation and functioning in the socio-cultural context (S. Vasiliev, V. Gorsky).

In terms of studying the genre characteristics of the "philosophy of the text" are scientifically valuable works of V. Rudnev, G. Kosikov, M. Foucault, E. Benvenist, R. Bart, Y. Kristeva, which identified the essential characteristics of such concepts as "text", "discourse", "work" and separate their common and distinctive features. We consider as the productive opinion of L. Ovsienko, expressed in the article "Text in the aspect of research of philosophical hermeneutics". The researcher concludes that from the point of view of philosophical hermeneutics, the text is in fact everything that exists in the world. Text is understood as "objective, real independence" in relation to any subject, including the author and the interpreter. The depth and completeness of

17 Selivanova, O. O. (2007/2008). Suchasna linhvistyka: napriamy ta problemy [Modern linguistics: directions and problems] : pidruchnyk. Kyiv, Poltava : Dovkillia. $712 \mathrm{p}$.

${ }^{18}$ Beniuk, O. B. Mystetstvo yak tekst u filosofskii hermenevtytsi [Art as a text in philosophical hermeneutics]. URL: http://knukim.edu.ua/wp-content/uploads/nuk_konf/ 19/8.pdf. 
understanding the text is directly related to its entry into the hermeneutic circle, which is the basic principle of understanding the text, based on the relationship of its parts and generally himself. Understanding of text in general, based on understanding of its individual parts and to understand the parts it is necessary to understand the text in general ${ }^{19}$.

The author highlights the following features of the text from the point of view of hermeneutics:

1. Structure (the structure of the text can be organized in different ways each time).

2. Nonlinearity (all elements of the text are not presented in a linear sequence, but as a system of all possible transitions and connections between them. In this case, the material can be read in any sequence, forming different linear texts (hypertext principle)).

3. Understanding (the reader perceives only part of the content of the author's text, because the level of its perception is limited by the sociohistorical context, education, era, culture, age, etc.). "Part of the content of the text always slips away from understanding" 20 .

4. Content (the text is able to accumulate content; it means that in this case the recipient understands more than was laid by the author ${ }^{21}$.

In modern philosophical science became popular such direction as philosophical hermeneutics (translated from the ancient Greek as an explanation, interpretation). This is explained by the fact that the difficulties of finding the true meaning of human existence and ways to resolve the contradictions of the modern world, was replaced by this philosophy (the search for interpretations with the active use of conventionalist semantics).

According to A. Bakreu and I. Shpachynsky, in philosophy, interest to hermeneutics as a methodological principle of humanities knowledge arose, due to misunderstandings, lack of agreement between people in the process of communication, as well as differences in understanding the same philosophical texts ${ }^{22}$.

${ }^{19}$ Ovsiienko, L. (2014). Tekst v aspekti doslidzhen filosofskoi hermenevtyky [The text in the aspect of research of philosophical hermeneutics]. Teoretychna $i$ dydaktychna filolohiia : zbirnyk naukovykh prats. Vyp. 18. Pereiaslav-Khmelnytskyi. P. 92-96.

20 Riker, P. (1998). Paradigma perevoda [Paradigm of translation]. URL: http://www.quebec.ru/Translation/Page1.htm.

${ }^{21}$ Ovsiienko, L. (2014). Tekst v aspekti doslidzhen filosofskoi hermenevtyky [The text in the aspect of research of philosophical hermeneutics]. Teoretychna i dydaktychna filolohiia : zbirnyk naukovykh prats. Vyp. 18. Pereiaslav-Khmelnytskyi. P. 95.

22 Bakreu, A. S. Shpachynskyi, I. L. (2019). Osoblyvosti hermenevtyky yak filosofskoi kontseptsii KhKh st. [Features of hermeneutics as a philosophical concept of the XX century]. Young Scientist, 12 (76), December, P. 247-250. 
From its ancient origins, hermeneutics is the art of interpretation, explanation of texts and despite the assertion of innovative ideas of philosophical hermeneutics, its original meaning is still relevant today. Interpretation of various semantic materials (cultural values, traditions, experience in various areas of socio-cultural activities of man) is through language and texts.

At the same time, as the representative of philosophical hermeneutics P. Reeker emphasizes, "hermeneutics is not limited to an objective structural analysis of texts, nor to the subjective existential characteristics of the authors of these texts; the main subject of her research are the worlds discovered by these authors and texts. Only by understanding the worlds, real and possible, discovered through language, we can understand ourselves"23.

In the European tradition, hermeneutics has long been seen as the art of interpreting texts and other expressions of thought. In fact, hermeneutics concerned everything that makes sense and requires interpretation as a special procedure for understanding meaning and preventing disagreements. In antiquity, the art of explaining translation and interpretation was called hermeneutics. This type of activity got its name from the Greek god Hermes (in Greek mythology, Hermes is a messenger of the god Zeus, who had to explain to people the meaning of messages from the latter).

Christian writers understood hermeneutics as the art of interpreting the Bible. The opinions of well-known philosophers, supporters of hermeneutic theories (F. Schleiermacher, F. Ast, W. Dilthey, M. Heidegger, G.-G. Gadamer, K.O. Apel, J. Habermas, P.) do not lose relevance against the background of modern challenges. Reeker, W. von Humboldt, A. Potebnya, J. Derrida, T. Kuhn, P. Feisrabend, R. Rotry, D. Davidson, M. Foucault, F. Lyotard, J. Deloch, etc.), who emphasized development of spiritual culture as a determining force of social development and individuality, as a prerequisite for all existence.

Friedrich Schleiermacher's "Universal Hermeneutics" had to summarize all considerations about the phenomenon of understanding its laws and principles, in contrast to specialized practices of interpretation, which are different depending on the text: religious, philological or legal. The subject area of "universal hermeneutics" was the spiritual communication of people, which is realized through language. Schleiermacher was the first who formulate the main principles of philosophical hermeneutics, as well as the

23 Riker, P. (2003). Mit yak poslanets ynshykh svitiv (Rozmova R. Kerni z P. Rikerom) [Myth as an envoy of other worlds (Conversation of R. Kearney with P. Reeker)]. Manipuliatsiia svidomistiu. Kulturolohichnyi chasopys ' $T$ ”. № 30. URL: http://www.ji.lviv.ua/n30texts/riker.htm. 
principle of the hermeneutic circle as a methodological basis for interpretation: unity must be understood on the basis of parts, and the understanding of parts implies an idea of the unity meaning. (the unity is the spirit of the era, and part - the work or author) ${ }^{24}$.

But the appearance of hermeneutics as a system and set of methods for adequate interpretation and explanation of texts in their broadest sense is associated primarily with the name of the German theologian and philosopher Friedrich Schleiermacher. In his many works on philosophy, theology, and aesthetics, the problem of the procedure of understanding as a separate field of study arises, in other words, he emphasize "understanding" as the central category of hermeneutics.

In studies of V. Dilthey, hermeneutics is not a separate component, but is the essence of historical knowledge, based on the procedures of understanding and interpretation. Under the text, the philosopher understands all the sign-symbolic reality, the world of culture, which is fixed primarily in language.

Among the research studies, which describe special branches of hermeneutic analysis, a special place is occupied by the works of O.O. Potebny (philological), LA Markova (theological), P. Reeker (psychoanalytic, religious), G. Albert (historical), VM Meisersky (medieval interpretation), IA Vasylenko (political), G Seifert (legal hermeneutics - the hermeneutics of lifell).

Hermeneutics is a theory and art of explanation, which aims to reveal the meaning of the text, based on its objective (meanings of words and their historically determined variations) and subjective (intentions of the authors) bases.

M. Heidegger made an attempt to transform hermeneutics into a special philosophy - the philosophy of understandindg the text, where the word "text" - is any information between two subjects of understanding: written text, verbal text (language), intonation, look, gesture, silence.

In hermeneutics, "text" is a certain written source (written fixation of sound language, which is characterized by meaning, significance, value), the primary given (reality) and the starting point of any humanities discipline. And in phenomenology, it is the content and the very structure of consciousness, the fundamental education that allows us to think about the objects that fall into the center of research. The concept of "text" is a unifying phenomenon for phenomenology and hermeneutics ${ }^{25}$.

${ }^{24}$ Ricoeur, P. (1973). The Task of Hermeneutics. Philosophy Today. Vol. 17, № 2/4, P. 112-128.

${ }^{25}$ Hrytsaienko, P. (2007). Humanitarne piznannia : sutnist ta osoblyvosti poniattia [Humanities: the essence and features of the concept]. Filosofiia. Politolohiia. Vyp. 84-86. P. 121-124. 
Pretty often the subject of research in hermeneutics, is the text. The text hermeneutics explore the interpretation of its deep content, its translation by studying the structure and semiotic nature of language, analysis of: historical, philosophical, religious and other data, related to a particular literary work ${ }^{26}$.

Hryshchenko also indicates, that the subject basis of hermeneutic methodology is the text as a sign-symbolic system in its socio-cultural and historical context. Language is a means of analyzing humanitarian phenomena. Therefore, in many hermeneutic concepts, language is a central problem $^{27}$. The central problem of hermeneutics, according to G. von Wrigt, is the idea of language and language-oriented concepts: "meaning", "intensity", "interpretation", "understanding". This feature is reflected in the name "hermeneutics", which means the art of interpretation ${ }^{28}$.

Nowadays in Ukraine, despite the intensification of research on hermeneutics, there is a lack of research that highlights the results of the analysis of genres of pedagogical communication. An extremely interesting Ukrainian publication dedicated to hermeneutics is S. Kosharny's monograph "Near the Sources of Philosophical Hermeneutics",29, in which the author traces the beginnings of philosophical hermeneutics before M. Heidegger, as well as a significant contribution to the development of Ukrainian hermeneutics, made by S. Kvit, whose manual "Fundamentals of Hermeneutics" ${ }^{30}$ stands out against the background of a significant part of research products. In this paper, hermeneutics is considered as the oldest and most productive theory and practice of interpretation.

O. Saprykina in her study of hermeneutics as the art of understanding and interpreting the text says, that people faced the problem of understanding and interpretation in ancient times. First of all, it is an understanding of religious and artistic works. Created in ancient times, recorded from legends, their texts abounded in incomprehensible names, forgotten events, concepts and symbols - dark places. The sages of that time undertook to interpret them, to make them accessible and eloquent for

26 Selivanova, O. O. (2007/2008). Suchasna linhvistyka: napriamy ta problemy [Modern linguistics: directions and problems] : pidruchnyk. Kyiv. Poltava: Dovkillia. $712 \mathrm{p}$.

Hryshchenko, Ya. S. Hermenevtyka yak mystetstvo interpretatsii [Hermeneutics as an art of interpretation]. URL: http://www.kamts1.kpi.ua/ru/node/1017. [in Ukrainian].

${ }^{28}$ Wrigt, G. H. von (1986). Logikofilosofskie issledovaniya [Logicophilosophical research]. Moskva : Progress. 600 p.

${ }^{29}$ Kosharnyi, S. (1992). Bilia dzherel filosofskoi hermenevtyky [At the sources of philosophical hermeneutics]. Kyiv : Naukova dumka. 124 p.

${ }^{30}$ Kvit, S. M. (2003). Osnovy hermenevtyky [Fundamentals of hermeneutics] : navchalnyi posibnyk. Kyiv : Akademiia. 192 p. 
their contemporaries. This work required a broad worldview, deep knowledge and relevant skills. Not always the interpretation of one scientist was perceived by others, who, in turn, had their own explanations, sought out the reasons for the failure of their predecessors, offered their own ways of research and understanding of works. Thus, certain approaches and techniques, methods and methodologies of explanation were fixed, which gave the most effective and convincing results. Over time, it became clear that qualified interpretation requires not only ancient texts, but also innovations, because different people perceive the same text differently. The new generation opens new semantic faces in it, each epoch actualizes the content of the work in a new way, and in new cultural and historical conditions. The same content can take on a qualitatively different meaning - often quite far from the author's idea ${ }^{31}$.

Philosopher A. Polivoda, studying the historical progress of philosophical hermeneutics, denote its popularity in the twentieth century, which is caused by a combination of several factors: the long tradition of hermeneutics as an art of interpretation, synthesis in Gadamer's ideas of Schleiermacher, Dilthey, Husserl and Heidegger. After all, the general context of the chaotic twentieth century played an important role. There are many philosophical theories and courses, that have an impact nowadays: existentialism, structuralism and poststructuralism, analytical philosophy, philosophy of dialogue and etc. Due to the so-called "language turn" in philosophy, concepts focused on the problems of language and communication become influential. The evolution of hermeneutics - from method to philosophical course - can generally be described as a transition from the interpretation and understanding of texts to the understanding of being ${ }^{32}$.

O. Benyuk emphasizes that hermeneutics is the art of interpretation, explanation of texts from its most ancient origins and, despite the assertion of innovative ideas of philosophical hermeneutics, its original meaning is still relevant today. Interpretation of various semantic materials (cultural values, traditions, experience in various areas of socio-cultural activities of man) is through language and texts.

31 Saprykina, O. (2014). Suchasna literaturna hermenevtyka yak mystetstvo rozuminnia y interpretatsii khudozhnoho teksty [Modern literary hermeneutics as the art of understanding and interpreting an artistic text]. URL: file:///D:/Users/User/Downloads/ Npd_2014_3_23.pdf.

$\overline{32}$ Polivoda, A. Filosofska hermenevtyka. Mini-slovnyk kliuchovykh poniat [Philosophical hermeneutics. Mini-dictionary of key concepts]. URL: https://locusplace.org/ filosofska-germenevtyka-slovnyk-polivoda. 
Philosophical hermeneutics as a direction of modern philosophy has developed the problem of understanding texts to the problems of understanding the historical, spiritual, cultural life of $\operatorname{man}^{33}$.

No less important are studies in the field of pedagogical hermeneutics.

Pedagogical communication by its nature is always hermeneutic, because its main feature is the desire for mutual understanding of the educational process subjects, which requires a detailed study of the problem of understanding the pedagogical communication genres. The components of the teachers professional activity are the text (dialog, monologue), its understanding, interpretation, interpretation, etc. The problem of understanding becomes especially relevant: students must understand speech of the teacher, texts in the textbook; the teacher must find common ground with students, colleagues, parents. At the present stage it is important to understand the different types of texts: integral, interrupted and mixed.

Interpretation and understanding of texts is provided by specific methodological means (hermeneutic circle, methods of questions and answers, contextual method, special logical means, semiotic and psychological techniques). The relationship between understanding and explanation in the hermeneutic methodological standard, implies the advantage of understanding methods due to the characteristics of the subject of study. In modern hermeneutic concepts there are no absolutization of understanding. It should be noted that at the level of everyday consciousness, the terms "understanding" and "explanation" do not differ. Any explanation promotes understanding, and, conversely, in the case of understanding, there is usually always an answer to the question of the reason that led to the situation of understanding. Therefore, the advantage of methods of understanding is quite relative $\mathrm{e}^{34}$.

Note that the analysis of this attitude to the texts, allows to identify the grounds for their hermeneutic typology. In the works of G. G. Gadamer it is popossible to find a special analysis texts types in terms of how their content (their semantic scope) determines the appropriate reading strategy. Thus, he mentions as a negative example "notes", daily records or telegrams that do not have hermeneutic difficulties in reading ${ }^{35}$. They are opposed by the most complex and hermeneutically rich (promising) texts - poetic and

${ }^{33}$ Beniuk, O. B. Mystetstvo yak tekst u filosofskii hermenevtytsi [Art as a text in philosophical hermeneutics]. URL: http://knukim.edu.ua/wp-content/uploads/nuk_ konf/19/8.pdf.

${ }^{34}$ Kuznetsov, V. G. (1991). Germenevtika i gumanitarnoe poznanie [Hermeneutics and Humanities]. Moskva : MGU. 191 p.

${ }^{35}$ Gadamer, G. G. (1991) Aktualnost prekrasnogo [Relevance of the beautiful] / pod redaktsiey V. S. Malahova. Moskva : Iskusstvo. 136 p. 
philosophical (and between the first and second there are essential similarities).

One of the central concepts of philosophical hermeneutics is the concept of hermeneutic circle.

The explanation of figure of the hermeneutic circle was offered by Ast and Schleiermacher in the XIX century. The hermeneutic circle here refers to the procedure of understanding the text - it is a consistent movement from part of the text to understanding its full meaning and back to the part. In the romantic hermeneutics of the XIX century, the hermeneutic circle was interpreted as an opportunity to be equal with the author and to begin a dialogue with him. The procedure of understanding the text and the figure of the author, involved erasing the mediating role of the work as a symbol of spatio-temporal distance.

The concept of the hermeneutic circle evolved with the acquisition of hermeneutics ontological issues. With the formation of philosophical hermeneutics in the works of Heidegger and Gadamer, the hermeneutic circle is not used to work exclusively with texts, but acquires the features of a general procedure for understanding being. The movement of understanding is described as a constant request to the world and an outline of the expected meanings, which are clarified, affirmed or leveled in the process of expanding the horizon of knowledge. It is in the hermeneutic circle, subject encounters his own pre-understandings as an acquired collective experience. There, he is able to stand against tradition or persuaded in hus own prejudices.

For Heidegger's hermeneutics, the hermeneutic circle is a sphere of actualization of meaning as a request for intelligibility. "Meaning as an existential reveals, that the fundamental ontological structure of existence is the hermeneutic circle" ${ }^{\text {, }}$, - explains the position of Heidegger Bogachev. Meaning appears in the hermeneutic circle on the basis of preunderstandings through, understanding in a predetermined horizon of interpretation. Gadamer gives the hermeneutic circle a historical dimension, arguing that the movement of understanding takes place in the effective historicity of being.

\section{CONCLUSIONS}

Theoretical analysis of special literature in retrospect showed that genealogy as a branch of linguistics is directly related to philosophy, stylistics, $336 \mathrm{p}$.

${ }^{36}$ Bohachov, A. (2011). Dosvid i sens [Experience and meaning]. Kyiv : Dukh i litera. 
linguopragmatics, literary theory and stood out as a section of linguistics in the twentieth century, although its origins date back to antiquity.

Scientific works indicate that today there are many definitions of the term "genre". This is an indicator of the multi-vector orientation of research. An attempt to interpret the essence of genres, their fundamentally new rethinking took place under the influence of literary approaches, as well as the theory of speech genres M. Bakhtin, which significantly influenced the modern vision of the genesis and features of different genres.

The category of the genre is inextricably linked with the concept of "text". The versatility of the text involves different approaches to its definition. Text as an elementary (basic) unit of speech - a phenomenon not only linguistic but also extralinguistic. The phenomenon of the text and the related range of issues have been the subject of careful analysis in the philosophical aspect. Traditionally, this analysis focuses mainly on the problems of understanding, interpretation, meaning formation and functioning in the socio-cultural context.

Determine the content of the text, based on its purpose (the meaning of words and their historically determined variations) and subjective (intentions of the authors) bases, called hermeneutics - theory and art of explanation.

Today, hermeneutic research is conducted in various fields of humanities. In addition to philosophical hermeneutics, the most common is linguistic hermeneutics. In this context, research focuses mainly on the interpretation of the dialogic relationship between the knowing subject and the text as an object of cognition. Designing ideas and principles of hermeneutics in modern linguistics of the text, by O. Selivanova ${ }^{37}$, is one of the promising areas of this field of linguistics, especially in terms of solving a qualitatively new level of the problem of text interpretation.

Equally important is research in the field of pedagogical hermeneutics, bcause pedagogical communication always has hermeneutic in its nature. A distinctive feature of pedagogical communication is the desire for mutual understanding of the subjects of the educational process. That's why, the problem of understanding the genres of pedagogical communication, requires detailed study. The problem of understanding oral and written, dialogical and monologue texts becomes especially relevant. At the present stage, it is important to understand the different types of texts: whole, interrupted, mixed. Therefore, at the time of research in the field of pedagogical hermeneutics.

37 Selivanova, O. O. (2007/2008). Suchasna linhvistyka: napriamy ta problemy [Modern linguistics: directions and problems] : pidruchnyk. Kyiv. Poltava: Dovkillia. $712 \mathrm{p}$. 


\section{SUMMARY}

In the proposed chapter, there was an attempt to determine the semantic load of the concepts "genre", "text" in the context of philosophical and pedagogical hermeneutics. Particular attention is paid to the problem of understanding these concepts as multifaceted phenomena. It is concluded that the problem of understanding the genres of pedagogical communication needs to be studied in detail.

\section{REFERENCES}

1. Kemerov, V. E. Kerimov, T. H. (2003). Sotsialnaya filosofiya [Social philosophy] : slovar. Moskva : Akademicheskiy proekt. 560 p.

2. Nikolyukin, A. N. (2001). Literaturnaya entsiklopediya terminov i ponyatiy [Literary encyclopedia of terms and concepts]. Moskva : Intelvak. $1600 \mathrm{p}$.

3. Reber, A. (2000). Bolshoy tolkovyiy psihologicheskiy slovar [Big explanatory psychological dictionary]. Moskva : Veche, AST. Tom 2. 560 p.

4. Galitskih, E. O. (2007). Germenevticheskiy podhod k formirovaniyu yazyikovoy lichnosti na urokah literaturyi [A hermeneutic approach to the formation of a linguistic personality in literature lessons]. Russkaya literatura $v$ formirovanii sovremennoy yazyikovoy lichnosti. SanktPeterburg. P. 38-45.

5. Johns M. Ann (1995). Genre and Pedagogical Purposes. Genre and Pedagogical Purposes San Diego State University. Journal of second language writing, 4 (2), P. 181-190. URL: https://www.sciencedirect.com/ sdfe/pdf/download/eid/1-s2.0-1060374395900063/first-page-pdf.

6. Halych, O., Nazarets, V., Vasyliev, Ye. (2000). Teoriia literatury [Theory of literature]. Kyiv : Lybid. P. 251

7. Bahtin, M. I. (1979). Problemyi rechevyih zhanrov [Problems of speech genres]. Estetika slovesnogo tvorchestva. Moskva : Iskusstvo. P. 237-280.

8. Bahtin, M. (1975). Voprosyi literaturyi i estetiki. Issledovaniya raznyih let [Questions of literature and aesthetics. Research of different years]. Moskva : Hudozhestvennaya literatura. $500 \mathrm{p}$.

9. Yakhontova, T. V. (2009). Linhvistychna henolohiia naukovoi komunikatsii [Linguistic genealogy of scientific communication] : monohrafiia. Lviv : Vydavnychyi tsentr LNU imeni Ivana Franka. 420 p.

10. Turaeva, Z. Ya. (1986). Lingvistika teksta: (Tekst: struktura i semantika) [Linguistics of the text: (Text: structure and semantics)]. Moskva : Prosveschenie. $126 \mathrm{p}$.

11. Galperin, I. R. (1981). Tekst kak ob'ekt lingvisticheskogo issledovaniya [Text as an object of linguistic research]. Moskva : Nauka. 138 p. 
12. Selivanova, E. A. (2002). Osnovyi lingvisticheskoy teorii teksta i kommunikatsii [Foundations of linguistic theory of text and communication] : monografiya. Kiev : TsUL, Fitosotsiotsentr. P. 600-601.

13. Yeshchenko, T. A. (2009). Linhvistychnyi analiz tekstu [Linguistic analysis of the text] : navchalnyi posibnyk. Kyiv : Akademiia. 263 p.

14. Ukrainska mova. Entsyklopediia (2007). [Ukrainian language. Encyclopedia] / Redkolehiia : Rusanivskyi V. M., Taranenko O.O., Ziabliuk M.P. ta inshi. 3-e vydannia, zi zminamy i dopovnenniamy. Kyiv : Ukrainska entsyklopediia imeni M. P. Bazhana. 856 p.

15. Selivanova, O. O. (2007/2008). Suchasna linhvistyka: napriamy ta problemy [Modern linguistics: directions and problems] : pidruchnyk. Kyiv, Poltava : Dovkillia. 712 p.

16. Beniuk, O. B. Mystetstvo yak tekst u filosofskii hermenevtytsi [Art as a text in philosophical hermeneutics]. URL: http://knukim.edu.ua/wpcontent/uploads/nuk_konf/19/8.pdf.

17. Ovsiienko, L. (2014). Tekst v aspekti doslidzhen filosofskoi hermenevtyky [The text in the aspect of research of philosophical hermeneutics]. Teoretychna $i$ dydaktychna filolohiia : zbirnyk naukovykh prats. Vypusk 18. Pereiaslav-Khmelnytskyi. P. 92-96.

18. Riker, P. (1998). Paradigma perevoda [Paradigm of translation]. URL: http://www.quebec.ru/Translation/Page1.htm.

19. Bakreu, A. S. Shpachynskyi, I. L. (2019). Osoblyvosti hermenevtyky yak filosofskoi kontseptsii KhKh st. [Features of hermeneutics as a philosophical concept of the XX century]. Young Scientist, 12 (76), December, P. 247-250.

20. Riker, P. (2003). Mit yak poslanets ynshykh svitiv (Rozmova R. Kerni z P. Rikerom) [Myth as an envoy of other worlds (Conversation of R. Kearney with P. Reeker)]. Manipuliatsiia svidomistiu. Kulturolohichnyi chasopys “I”. № 30. URL: http://www.ji.lviv.ua/n30texts/riker.htm.

21. Ricoeur, P. (1973). The Task of Hermeneutics. Philosophy Today. Vol. 17, № 2/4, P. 112-128. [in English].

22. Hrytsaienko, P. (2007). Humanitarne piznannia : sutnist ta osoblyvosti poniattia [Humanities: the essence and features of the concept]. Filosofiia. Politolohiia. Vyp. 84-86. P. 121-124.

23. Selivanova, O. O. (2007/2008). Suchasna linhvistyka: napriamy ta problemy [Modern linguistics: directions and problems] : pidruchnyk. Kyiv, Poltava : Dovkillia. 712 p.

24. Wrigt G. H. von (1986). Logikofilosofskie issledovaniya [Logicophilosophical research]. Moskva : Progress. 600 p.

25. Kosharnyi, S. (1992). Bilia dzherel filosofskoi hermenevtyky [At the sources of philosophical hermeneutics]. Kyiv : Naukova dumka. 124 p. 
26. Kvit, S. M. (2003). Osnovy hermenevtyky [Fundamentals of hermeneutics] : navchalnyi posibnyk. Kyiv : Akademiia. 192 p.

27. Polivoda A. Filosofska hermenevtyka. Mini-slovnyk kliuchovykh poniat [Philosophical hermeneutics. Mini-dictionary of key concepts]. URL: https://locusplace.org/filosofska-germenevtyka-slovnyk-polivoda.

28. Beniuk, O. B. Mystetstvo yak tekst u filosofskii hermenevtytsi [Art as a text in philosophical hermeneutics]. URL: http://knukim.edu.ua/wpcontent/uploads/nuk_konf/19/8.pdf.

29. Kuznetsov, V. G. (1991). Germenevtika i gumanitarnoe poznanie [Hermeneutics and Humanities]. Moskva : MGU. 191 p.

30. Gadamer, G. G. (1991) Aktualnost prekrasnogo [Relevance of the beautiful] / pod redaktsiey V. S. Malahova. Moskva : Iskusstvo. $136 \mathrm{p}$.

31. Bohachov, A. (2011). Dosvid i sens [Experience and meaning]. Kyiv : Dukh i litera. $336 \mathrm{p}$.

32. Selivanova, O. O. (2007/2008). Suchasna linhvistyka: napriamy ta problemy [Modern linguistics: directions and problems] : pidruchnyk. Kyiv, Poltava : Dovkillia. 712 p.

\section{Information about the author: \\ Goroshkina Olena Mykolaivna,}

Doctor of Pedagogic Sciences, Professor,

Head of the Department of Teaching Ukrainian Language and Literature

National Academy of Educational Sciences of Ukraine

52, Sichovykh Striltsiv str., Kyiv, Ukraine, 04053 orcid.org/0000-0002-0378-888X

Mordovtseva Natalia Valeriivna,

Candidate of Pedagogic Sciences,

Associate Professor at the Department of Philological Disciplines Institute of Pedagogy and Psychology of State Institution Luhansk Taras Shevchenko National University 1, Gogol Squ., Starobilsk, Luhansk Region, Ukraine, 92703 orcid.org/0000-0002-1827-9404 